\title{
FACTORS AFFECTING INAPPROPRIATE PRESCRIPTION OF ANTIBIOTICS AND THE EMERGENCE OF ANTIBIOTIC RESISTANCE IN PATIENTS IN PRIMARY HEALTH CARE
}

\author{
Katarina Raspopovic1,3, Slobodan Jankovic ${ }^{2}$, Valentina Opancina ${ }^{3}$ \\ ${ }^{1}$ Health Center Danilovgrad, Danilovgrad, Montenegro \\ ${ }^{2}$ University of Kragujevac, Serbia, Faculty of Medical Sciences, Department of Pharmacology and toxicology \\ ${ }_{3}$ University of Kragujevac, Serbia, Faculty of Medical Sciences
}

\section{FAKTORI KOJI UTIČU NA NEOPRAVDANO PROPISIVANJE ANTIBIOTIKA I POJAVU REZISTENCIJE NA ANTIBIOTIKE KOD PACIJENATA U PRIMARNOJ ZDRAVSTVENOJ ZAŠTITI}

\author{
Katarina Raspopović1,3, Slobodan Janković2, Valentina Opančina ${ }^{3}$ \\ ${ }^{1}$ Dom zdravlja Danilovgrad, Danilovgrad, Crna Gora \\ ${ }^{2}$ Univerzitet u Kragujevcu, Srbija, Fakultet medicinskih nauka, Katedra za farmakologiju i toksikologiju \\ ${ }^{3}$ Univerzitet u Kragujevcu, Srbija, Fakultet medicinskih nauka
}

\begin{abstract}
Introduction. Increasing resistance to antibiotics is of great importance for health professionals around the world. The correlation between the use of antibiotics and rates of resistance has long been established. Physicians who work in primary health care make up a large part of health care personnel responsible for the use of these drugs. This study reveals factors that influence unduly prescribing antibiotics and the emergence of resistance to antibiotics in primary health care.

Methodology. This study has been conducted at the Health center Danilovgrad, Montenegro from November 1 st 2015 to June 1st 2016. We used a qualitative method-focus group, where one group consists of 8 members (six doctors for adults, 1 pediatrician am 1 pharmacist) and moderator. Based on previous systematic reviews, we made the agenda, which was followed during the group meetings to facilitate the identification of factors. During discussions within the meetings group audio recordings were made, and then their transcripts were individually analyzed by the researchers.

Results. Our study showed that factors affecting the prescription of medicines in primary health care are: personal interest of referring physician; fear of referring physician; external factors relating to the patient, pharmacist and the influence of the pharmaceutical industry; as well as the patients lack of knowledge and lack of information. Members of the group agreed that the emergence of resistance should be monitored at the level of healthcare institutions.

Conclusion. Identification of factors that influence inappropriate prescribing of antibiotics allows implementation of specific interventions with aim of improving antibiotic use and preventing antibiotic resistance, which is of special importance for developing countries where this problem affects their medical, economic and legal systems.
\end{abstract}

KEY WORDS: antibiotics, resistance, inappropriate prescribing, primary health care

\section{SAŽETAK}

Uvod. Povećana rezistencija na antibiotke predmet je brige zdravstvenih radnika širom sveta. Veza između upotrebe antibiotika $i$ nivoa rezistencije odavno je utvrđena. Lekari u primarnoj zdravstvenoj zaštiti čine veliki deo zdravstvenih radnika odgovornih za upotrebu ove grupe lekova. Ovom studijom se otkrivaju faktori koji utiču na neopravdano propisivanje antibiotika i pojavu rezistencije na antibiotike u primarnoj zdravstvenoj zaštiti.

Metodologija. Studija je sprovedena u Domu zdravlja Danilovgrad u Crnoj Gori u periodu od 1. 11. 2015. do 1. 6. 2016. godine. Korišćen je kvalitativni metod-fokus grupa, pri čemu grupu čini osam članova - šest doktora za odrasle, jedan pedijatar i jedan farmaceut, i moderator. Na osnovu sistematskog pregleda literature sastavljen je dnevni red (agenda), koji se pratio na sastancima grupe radi lakše indentifikacije faktora. Tokom sastanaka $i$ razgovora unutar grupe pravljeni su audio-zapisi, a potom su njihove transkripte istraživači pojedinačno analizirali.

Rezultati. Na propisivanje lekova u primarnoj zdravstvenoj zaštiti utiču sledeći faktori: lični interes lekara, strah lekara, spoljašnji faktori koji se odnose na pacijenta, farmaceuta i uticaj farmaceutske industrije, nedovoljno znanje pacijenta $i$ nedostatak informacija. Članovi grupe su se složili da pojavu rezistencije treba pratiti na nivou zdravstvenih institucija.

Zaključak. Indentifikacija faktora koji utiču na neopravdano propisivanje antibiotika omogućava sprovođenje određenih intervencija radi poboljšanja upotrebe antibiotika i sprečavanja pojave rezistencije na antibiotike, što je posebno važno u zemljama u razvoju, koje ovaj problem pogađa svakodnevno na zdravstvenom, ekonomskom i pravnom planu.

KLJUČNE REČI: antibiotici, rezistencija, neopravdano izdavanje lekova, primarna zdravstvena zaštita 


\section{INTRODUCTION}

Management of antimicrobial therapy is defined as "optimal choice, dosage and duration of treatment with antibiotics, which leads to the best clinical results for the treatment or prevention of disease, with minimal toxicity for the patient and minimal impact on the future resistance" (1).

Antibiotic resistance is a growing problem and the subject of scientific research of international significance $(1,2)$. It is connected with the consumption of antibiotics (AB) by both individuals and communities, and the consumption of certain groups of antibiotics $(3,4)$. In Europe, the prescribing of antibiotics varies in different countries, whereby antibiotics are prescribed more frequently in the southern Europe (5). Decades ago there were doubts concerning relationship between the use of $\mathrm{AB}$ and the spread of antibiotic resistance (6). As a result of European initiatives, studies were performed with the results of clear correlation between the rate of resistance and use of $\mathrm{AB}$ (penicillin and fluoroquinolones) $(6,7)$. It is also shown that respiratory infections as well as infections of ear, nose and throat are the most common reasons for patients visit to primary care and treatment with antibiotics (8).

Over the past 30 years, the development of new antibiotics has slowed significantly, and our ability to treat rising infections caused by resistant agents is limited day by day (9). Thousands of people die every year from infections caused by multi-resistant bacteria (10). The reasons for the slow development of antibiotics are simple: drug development is a risky and expensive, and medicines for the treatment of infections are not as profitable as those for the treatment of chronic diseases $(9$, $10)$.

There are national guidelines for rational use of antibiotics in primary care in Montenegro. These guidelines are based on evidence and their goal is to help physicians in making decisions about appropriate health care, i.e. appropriate antibiotics therapy (11). However Montenegro, as well as other developing countries, are still dealing with the problem of inappropriate prescription of antibiotics.

The aim of this study is to identify factors that affect improperly prescribing of antibiotics, which will further facilitate the implementation of specific interventions to improve the use of antibiotics and the emergence of antibiotic resistance in our conditions.

\section{MATERIALS AND METHODS}

This study has been conducted at the Health center Danilovgrad, Montenegro during time period from November 1st 2015 to June 1 st 2016. It was approved by the Ethics Committee of Health center Danilovgrad.
The study involved primary care physicians and pharmacists in the health center and pharmacies in Danilovgrad, Montenegro. According to the 2011 census, the total population in Montenegro is 620029 and the municipality of Danilovgrad has 16.523 inhabitants (12). In Montenegro, antibiotics may be issued only by prescription of referring physician.

Our study was designed as qualitative focus group (FG) study. This qualitative method provides better assessment of all aspects of the problem thanks to the interaction between group members and at the same time it is a quick way to gather information based on the subjective assessment of the participants (13).We performed systematic review of the literature and based on that, theoretical model was built with the purpose of creating agenda that was to be followed during the meetings of the group in order to facilitate the identification of attitudes and factors (13).

One focus group FG consisted of 8 members (six doctors for adults, 1 pediatrician am 1 pharmacist and moderator. The main focus of our groups was to examine factors / attitudes that influence prescribing $\mathrm{AB}$ and the emergence of antibiotic resistance. During discussions within the meetings group audio recordings were made, and then their transcripts were individually analyzed by the researchers.

Categories defined in the agenda consisted of groups of questions related to the specific issue of $\mathrm{AB}$ use, and these categories were: 1) the process of prescribing antibiotics, 2) compliance with national guidelines for rational use of antibiotics, 3) the consequences of the abuse of antibiotics. The first category consists of three sub-categories: a) a group of antibiotics that are used most and least, b) the most common illness for which antibiotics were prescribed, c) factors affecting the process of prescribing antibiotics (fear, lack of knowledge, personal interests, external factors).

\section{Focus group meetings}

The total number of physicians in primary health care at the Health Center in Danilovgrad is ten, 2 of them are pediatricians, and total number of pharmacists is 4 . All doctors and pharmacists were contacted by telephone or email, informed about the study and its objective and invited to participate in a focus group. Seven physicians and 1 pharmacist accepted to participate in the group. The focus group was conducted by a researcher who coordinated the participation of members of the group following created agenda. One focus group was formed consisting of six physicians, one pediatrician and one pharmacist. Two meetings of FG were held in the Health Center in Danilovgrad in November 2015 and February 2016, in advance agreed time period. 
Participants were informed about the use of sound recorder during the meetings of the FG, confidentiality was guaranteed, and the use of their personal information was excluded. All of the participants signed the written consent. Conversation within the group was filmed using a digital recorder. First meeting lasted 80 minutes and second meeting lasted 85 minutes. Participants were coded by gender (M-male, F-female) and number of meeting (1 and 2), for example M1, F2, etc. In order to prevent the occurrence of prejudices related to the interpretation, the procedure was accompanied by an independent researcher.

\section{Data analyses}

Audio recordings were processed to the transcription, and after that notes were made about different attitudes shown during the focus group discussions. Attitudes containing relevant information have been identified in accordance with pre-defined categories, in order to achieve the objectives of the study. Records have not been presented electronically, due to the fact that the use of specific statistical programs focus only on analyzes that include a large number of interviews, which is not the case in this study.

\section{RESULTS}

Focus group members were asked to share their opinion on the next topics: the process of prescribing antibiotics, diseases that are most commonly treated with antibiotics, factors that influence prescribing antibiotics, compliance of National guidelines for rational use of antibiotics, consequences of irrational use of $\mathrm{AB}$ and suggestions for improving the use of antibiotics.

The first item on the agenda was related to the question of which AB groups are most commonly used and which are used the least. Results have shown that the most commonly used group of antibiotics are beta lactams (amoxicillin in the first place), followed by macrolides and fluoroquinolones. The least prescribed are cephalosporins, erythromycin, clarithromycin, as well as newer antibiotics, and those with more side effects.

Table 1. The main factors that affect unduly prescribing of antibiotics in primary health care and the emergence of antibiotic resistance

\begin{tabular}{|c|c|}
\hline Factors: & Focus group members statements: \\
\hline Physicians self-interest: & $\begin{array}{l}\text { "The fact is that if I don't prescribe antibiotics they (patients) will go to another } \\
\text { doctor who will prescribe an antibiotic, which leads to conflict with the patient, then the } \\
\text { patient is asked to switch to another doctor, and small number of patients results in lower } \\
\text { salaries." (M1); } \\
\text { "I had a case of parents who brought the child with the flu, who told me that if I } \\
\text { don't prescribe an antibiotic, they will bring the child to a private doctor who will prescribe } \\
\text { an antibiotic." (F5) }\end{array}$ \\
\hline Physician's fear: & $\begin{array}{l}\text { "If a patient comes to me repeatedly with the same symptoms, although it refers to a } \\
\text { virus, I will give an antibiotic, so I'm calm, because who knows with what can the illness be } \\
\text { upgraded to." (F2); } \\
\text { "In chronic patients with chronic obstructive pulmonary disease or heart failure, } \\
\text { when there is the least suspect on bacterial infection, an antibiotic should be given, do not } \\
\text { leave the patient waiting long time as he/her can easily end up hospitalized." (M2); } \\
\text { "If in doubt, we are not sure what to prescribe, in this case, better to give an } \\
\text { antibiotic, because what if the infection is spreading, and it transfers to a healthy population." } \\
\text { (F4) }\end{array}$ \\
\hline $\begin{array}{l}\text { External factors } \\
\text { related to the patient, } \\
\text { pharmacists } \\
\text { pharmaceutical } \\
\text { industry: }\end{array}$ & $\begin{array}{l}\text { "A patient often does not take the medicine when you prescribe it or it is wrongly } \\
\text { taken." (M1); } \\
\text { "(F1); "Pharmacists do not write on the box how is drug used correctly or write it wrong } \\
\text { prescription to the patient, and the patient then comes to beg for the recipe in order to justify } \\
\text { the antibiotic at the pharmacy "(F3); } \\
\text { promoting the drug they reduce its use" (F4), } \\
\text { "The influence of the pharmaceutical industry is so great because when they stop } \\
\text { particular disease, which could mislead public in general and that should be fought "(F2) }\end{array}$ \\
\hline $\begin{array}{l}\text { Patients lack of } \\
\text { knowledge and lack of } \\
\text { information: }\end{array}$ & $\begin{array}{l}\text { "The problem is a habit, a habit is difficult to change." (F4), } \\
\text { "Many doctors, especially older, do not follow modern trends in treatment, and stick } \\
\text { to the old school." (F3) }\end{array}$ \\
\hline
\end{tabular}


The following item was related to the diseases that are most commonly treated with antibiotics. It was concluded that respiratory illnesses, especially infections of the upper respiratory tract are the most frequently treated with $\mathrm{AB}$. The next group are urinary tract infections, and ear infections. The most common urinary tract infection is cystitis and the most frequent ear infection is otitis media. Even though they are not so frequent, local use of $A B$ is very characteristic in conjunctivitis and certain dermatological infection.

Among the factors that influence prescribing antibiotic, physicians in the first place put the symptoms and signs of illness, such as "I pay attention to the body temperature, whether the sputum is whitish, yellowish or greenish, which suggests to me if there is a viral or bacterial infection."(F1), then they state that their professional experience, the use of rapid diagnostic tests, compliance with national guidelines for good clinical practice are also of great importance. Our focus group showed also clear separation of four factors that influence AB prescription (Table 1).

Young doctors are increasingly focusing on the instructions of National guidelines in relation to the older colleagues. Older physicians find that it is good to appreciate guidelines, but it is often necessary to harmonize the treatment according to the current health condition of the patient, so that it is not always possible to follow the guidelines.

Most of the members of the FG shared the view that the problem of $\mathrm{AB}$ resistance is most frequent in urinary infections. The emergence of resistance should be monitored at the level of healthcare institutions. Patients who have a large impact on the emergence of antibiotic resistance are those who don't take the drug adequately and as required and those who treat themselves without the advice of doctors. Also pharmacists who issue antibiotics without a doctor's prescription and the emergence of a large number of inappropriate prescriptions both in general practice and dentistry, as well as the extended use of antibiotics are of great influence on irrational use of $\mathrm{AB}$.

Finally, we asked for suggestions on better AB use. Focus group members agreed that the most important is to improve access to rapid diagnostic tests. One of the members said: "What is needed is higher use of diagnostic tests and faster obtaining of their results for better decision making which are formed on a certain level of evidence." (F4); The other FG member stated that better access to the medical history of the patient through software, education of the population in order to decrease the pressure to prescribe antibiotics and awareness of the patient are very important for a good doctor-patient relationship: "It is necessary to inform people so that they know when is and when it isn't necessary to see a doctor." (F1). Other members agreed that continual medical education and possible existence of one health worker for every level of the institution with the ability of expert consultation for use of any drug could be of great importance.

\section{DISCUSSION}

Our study displayed the factors that affect unduly antibiotics prescribing in primary health care and the emergence of antibiotic resistance. The main factors were highlighted: personal interest of physician; physician's fear; external factors related to patients, pharmacists and pharmaceutical industry; patient's lack of knowledge and lack of information.

According to the physicians' opinion, AB are most commonly prescribed for upper respiratory tract infections including sinusitis, pharyngitis, tonsillitis and acute bronchitis 14. It was found that of the most frequent upper respiratory tract infection is pharyngitis, as a cause of pain in the throat, which is most common reason for $A B$ prescription (14-16). Urinary infections take the 2nd place as a reason for $\mathrm{AB}$ prescription $(15,16)$. Our focus group members had the same opinion and stated the important role of respiratory and urinary infections on $\mathrm{AB}$ prescription.

European Surveillance of Antimicrobial Consumption conclusions as well as published studies display beta lactams followed by macrolides as the most commonly prescribed AB which is in agreement with in Montenegro guidelines and recommendations for the use of antibiotics in primary care $(11,17)$. However, there are significant differences in antibiotic prescribing between countries of Europe, which cannot be calculated in relation to differences in morbidity.(18).

As one of the biggest problems related to compliance with the recommendations on the proper use of antibiotics, our study participants cited uncertainty in the assessment of disease etiology and diagnosis. As a possible solution to overcome this uncertainty they gave some recommendations such as better access to rapid diagnostic tests and the use of clinical guidelines. It has been shown that access to rapid diagnostic tests improve the use of antibiotics, as well as the respect of clinical guidelines which affects the rationalization of the use of antibiotics (19-22). Some study participants cited the option of deferred prescribing of antibiotics as a possible solution in equivocal cases and scheduling follow-up examination after a short time period (3-4 days). Factors that are also found to be significant are clinical experience of doctors and informed patients (23).

When it comes to the emergence of antibiotic resistance, opinions are divided. Most doctors consider that this is primarily a problem in the tertiary care while others say that the frequent occurrence of resistance 
happens at the primary level, particularly in respiratory and urinary infections. This perception can be explained by the fact that resistant cases are sent for further treatment to the clinics as a severe form of infections, giving a false picture of the resistance occurrence. Some studies have shown that one of the options to alert physicians to the importance of resistance to antibiotics is the introduction of mandatory publication of a report in case of patient with resistance to the antibiotic $(21,23)$. This is something that should be considered as a daily praxis, not only in Montenegro, but also in other developing countries.

Fear and self-interest of physicians are confirmed as factors that influence the prescribing of antibiotics in other similar studies (24-27). In our study, it was also shown that physicians have fear of treating patients who are emergent cases and who have another doctor as referring physician. In those cases, they are not familiar with patients' medical history and are afraid of possible unwanted complications. Self-interest of physicians could be diminished with the spread policy of deferred $\mathrm{AB}$ prescription among all physicians.

Certain published studies stated that $\mathrm{AB}$ prescription is greatly influenced by external factors relating to the pharmacists and the pharmaceutical industry which is in concordance with our results. It was shown that there is a significant relationship between the issuing of antibiotics without a prescription, and the development of resistance (28).

Although it is legally banned to issue antibiotics without a doctor's prescription, in pharmacies, this practice is still present in Montenegro. In addition to pharmacists, doctors in primary health care attribute part of the blame for improper use of antibiotics to other professionals such as dentists and surgeons. Regarding the first group, some studies show that antibiotics were prescribed indiscriminately, inappropriately and injudiciously to manage the oral disease (29). When it comes to the pharmaceutical industry, some studies have shown that its influence over the representatives of pharmaceutical sales significantly contribute to the inadequate prescription of drugs $(30,31)$.

This study has limitations specific to the use of qualitative methodology. One of the limitations is the small number of participants, something which limits the generalization of the study in other areas or countries. Among the advantages of the study is the fact that the interaction between members of focus groups creates certain ideas for solving the existing problems, which would otherwise be difficult to obtain without such interaction.

However, even though our study was conducted in Montenegro, it shouldn't necessarily be of importance only in this country. The problem that we displayed is of huge importance in other developing countries who are dealing with it on daily bases, and giving the right pointers could be significant for all of them, especially for countries with similar cultural and social behavior with Montenegro.

\section{ACKNOWLEDGEMENTS}

We thank the physicians and pharmacist who accepted to be participants in this study.

\section{CONFLICT OF INTEREST}

Authors don't report any conflict of interest.

\section{ABBREVIATIONS}

AB-antibiotics, FG- focus group, F-female study participant, M-male study participant

\section{REFERENCES}

1. World Health Organization. Global action plan on antimicrobial resistance. Geneva: World Health Organization; 2015. Available at: http:// www.who.int/drugresistance/global_action_plan/en/.

2. Laxminarayan R, Matsoso P, Pant S, et al. Access to effective antimicrobials: a worldwide challenge. Lancet 2016; 387: 168-75.

3. Adriaenssens N, Coenen S, Versporten A, et al. European Surveillance of Antimicrobial Consumption (ESAC): outpatient antibiotic use in Europe (1997-2009). J Antimicrob Chemother 2011; 66: vi3-12.

4. Tomson G, Vlad I. The need to look at antibiotic resistance from a health systems perspective. Ups J Med Sci2014; 119: 117-24.

5. Molstad S, Lundborg CS, Karlsson AK, et al. Antibiotic prescription rates vary markedly between 13 European countries. Scand J Infect Dis 2002; 34: 366-71.

6. Laxminarayan R, Duse A, Wattal C, et al. Antibiotic resistance-the need for global solutions. Lancet Infect Dis 2013; 13: 1057-98.

7. Mendelson M, Røttingen JA, Gopinathan U, et al. Maximising access to achieve appropriate human antimicrobial use in low-income and middle-income countries. Lancet 2015; 387: 188-98.

8. Nord M, Engstrom S, Molstad S. High and variable use of antibiotics in primary care. (Högochvarierandeförskrivningavantibiotika I primärvården). Lakartidningen 2013; 110: 1282-4.

9. Review on Antimicrobial Resistance Tackling a crisis for the health and wealth of nations. London, United Kingdom: Review on Antimicrobial Resistance; 2014. 
10. Nathan C, Cars O. Antibiotic resistance - problems, progress, and prospects. N Engl J Med 2014; 371: 1761-3.

11. Nikolić G, Simović S, Adžović A, Lakićević J. Racionalna primjena antibiotika $u$ primarnoj zdravstvenoj zaštiti. Nacionalne smjernice dobre kliničke prakse, Crna Gora, 2012.

12. Zvizdojević J, Radovanović B, Kolić E. Crna Gora u brojkama 2013, Zavod za statistiku Crne Gore Monstat, Podgorica 2013.

13. Mack N, Woodsong C, Macqueen K, Guest G, Namey E. Qualitative Research Methods: A Data Collector's Field Guide. Family Health International 2005.

14. Del Mar C, Glasziou P, Lowe JB, van Driel ML, Hoffmann T, Beller E. Addressing antibiotic resistance - focusing on acute respiratory infections in primary care. Aust Fam Physician 2012; 41: 839-40.

15. Dallas A, Magin P, Morgan S, et al. Antibiotic prescribing for respiratory infections: a cross-sectional analysis of the ReCEnT study exploring the habits of early-career doctors in primary care. Fam Pract 2015; 32: 49-55.

16. Linder JA. Antibiotic Prescribing for acute respiratory infections-success that's way off the mark: comment on „A cluster randomized trial of decision support strategies for reducing antibiotic use in acute bronchitis“. JAMA Intern Med 2013; 173: 273-5.

17. Surveillance of antimicrobial consumption in Europe 2012. Stockholm: ECDC; 2014.

18. Touboul-Lundgren P, Jensen S, Drai J, Lindbæk M. Identification of cultural determinants of antibiotic use cited in primary care in Europe: a mixed research synthesis study of integrated design „Culture is all around us“. BMC Public Health 2015; 15: 908.

19. Neumark T, Brudin L, Molstad S. Use of rapid diagnostic tests and choice of antibiotics in respiratory tract infections in primary healthcare - a 6-y follow-up study. Scand J Infect Dis 2010; 42: 90-6.

20. Murphy M, Bradley CP, Byrne S. Antibiotic prescribing in primary care, adherence to guidelines and unnecessary prescribing - an Irish perspective. BMC Fam Pract 2012; 13: 43.

21. Ackerman S, Gonzales R. The context of antibiotic overuse. Ann Intern Med 2012; 157: 211-2.
22. Bekkers MJ, Simpson SA, Dunstan F, et al. Enhancing the quality of antibiotic prescribing in primary care: qualitative evaluation of a blended learning intervention. BMC Fam Pract 2010; 11: 34.

23. Ostini R, Hegney D, Jackson C, Williamson M, Mackson JM, Gurman K, et al. Systematic review of interventions to improve prescribing. Ann Pharmacother 2009; 43: 502-13.

24. Strandberg EL, Brorsson A, Hagstam C, Troein M, Hedin K. „I'm Dr Jekyll and Mr Hyde“: are GPs' antibiotic prescribing patterns contextually dependent? A qualitative focus group study. Scand J Prim Health Care 2013; 31: 158-65.

25. Costelloe C, Metcalfe C, Lovering A, Mant D, Hay AD. Effect of antibiotic prescribing in primary care on antimicrobial resistance in individual patients: systematic review and meta-analysis. BMJ 2010; 340: c2096.

26. Hebert C, Beaumont J, Schwartz G, Robicsek A. The influence of context on antimicrobial prescribing for febrile respiratory illness: a cohort study. Ann Intern Med 2012; 15: 160-9.

27. Ternhag A, Grünewald M, Nauclér P, Wisell KT. Antibiotic consumption in relation to sociodemographic factors, co-morbidity, and accessibility of primary health care. Scand J Infect Dis 2014; 46: 888-96.

28. Marković-Peković V, Grubiša N. Self-medication with antibiotics in the Republic of Srpska community pharmacies: pharmacy staff behavior. Pharmacoepidemiol Drug Saf 2012; 21: 1130-3.

29. Konde S, Jairam LS, Peethambar P, Noojady SR, Kumar NC. Antibiotic overuse and resistance: A crosssectional survey among pediatric dentists. J Indian Soc Pedod Prev Dent. 2016; 34: 145-51.

30. Magrini N, Formoso G, MarataAM, et al. Randomised controlled trials for evaluating the prescribing impact of information meetings led by pharmacists and of new information formats, in General Practice in Italy. BMC Health Serv Res 2007; 28: 158.

31. Vancelik S, Beyhun NE, Acemoglu H, Calikoglu O. Impact of pharmaceutical promotion on prescribing decisions of general practitioners in Eastern Turkey. BMC Public Health 2007; 25: 7: 122. 